\title{
From Pine to Perfume
}

\author{
Gilles Sagorin, Emmanuel Cazeils, Jean-François Basset, and Maud Reiter*
}

\begin{abstract}
CST (Crude Sulfate Turpentine) is an upcycled, biomass raw material derived from pinewood, obtained as a by-product of the Kraft process from the pulp and paper industry. The current article provides an overview of major renewable perfumery ingredients obtained from CST-derived alpha- and beta-pinene to-date and part of the Firmenich manufacturing portfolio, post DRT acquisition.
\end{abstract}

Keywords: CST · Fragrance $\cdot$ Musk $\cdot$ Pinene $\cdot$ Renewable carbon $\cdot$ Turpentine

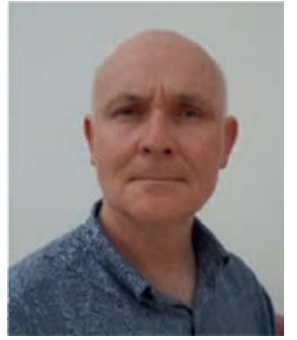

Dr. Gilles Sagorin is a Terpene Chemistry Expert at DRT-Firmenich in Castets (France). After a PhD in organophosphorus chemistry in Brest (France) in 1991, he worked for 8 years as a scientist (mainly on sphingolipids for the cosmetics industry) in a company specialised in custom synthesis (Panchim, France). Then, in 2000, he joined a flavour and fragrance company in Grasse (CharabotRobertet, France) as the head of R\&D in synthetic chemistry. He worked there for 5 years before moving to DRT (France) in 2005 as the R\&D Manager for Terpenes. His current work concerns the development of molecules from alpha-pinene, betapinene or acrolein. He is also in charge of the optimisation of the associated manufacturing processes.

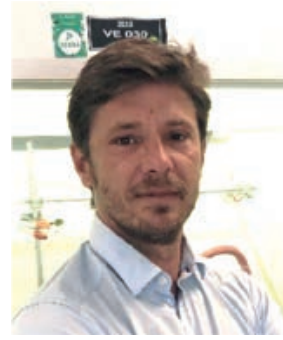

Dr. Emmanuel Cazeils is the Technical Manager of Strategic Raw Materials at the Procurement Division of DRT in Dax (France). Emmanuel received his undergraduate degree from University of Bordeaux (France) in 2004, followed by a $\mathrm{PhD}$ with Professor Alain Castellan at the same university. After postdoctoral work with Professor Ian Suckling at ScionResearch in Rotorua (New Zealand), Emmanuel joined DRT in 2009 in Vielle Saint-Girons (France) as a R\&D project manager. In 2019, Emmanuel moved to the Procurement Division at DRT, where he heads the technical management of strategic DRT raw materials mainly turpentine and rosin - with both suppliers and internal users.

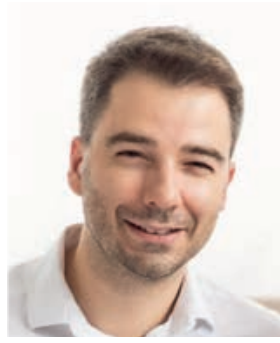

Dr. Jean-Francois Basset is currently a scientist in the R\&D department of Firmenich S.A. Geneva (Switzerland). Jean-Francois obtained his Master's degree at the Ecole Nationale Supérieure de Chimie de Mulhouse (France) in 2006. He then moved to Imperial College, London to carry out his PhD studies under the supervision of Prof. A. G. M. Barrett. In 2011, he started an industrial postdoctoral position at Firmenich S.A. Geneva and then in 2012 transferred to Firmenich Inc. (New Jersey) where he developed new automated high throughput screening methodologies. In 2017 he moved back to Firmenich S.A. Geneva to be part of the next generation processes team.

*Correspondence: Dr. M. Reiter, E-mail: Maud.REITER@firmenich.com R\&D Division of Firmenich S.A, Geneva, CH-1242 Satigny, Switzerland

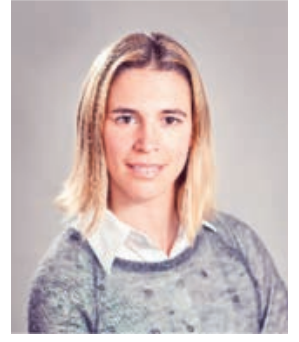

Dr. Maud Reiter is the Director of New \& Renewable Ingredients in the corporate R\&D Division of Firmenich S.A. in Geneva (Switzerland). Maud received her undergraduate degree from Imperial College, London, in 2002, followed by her DPhil with Professor Véronique Gouverneur at the University of Oxford. After postdoctoral work with Professor David MacMillan at Caltech/ Princeton University, Maud joined Merck \& Co. in 2008 in Rahway, NJ, USA as a medicinal chemist. In 2011, Maud moved to Firmenich, where she is overseeing the discovery of novel \& sustainable perfumery ingredients and, since October 2020, the implementation of renewable versions of existing ingredients. She is a core team member of the Swiss Women in Chemistry \& Suschem. ch networks and joined the SCS Board of Directors in June 2021.

\section{Introduction}

Wood is the most abundant biosourced feedstock on earth. Around one third of the world's land surface is covered by forests containing a total growing stock of more than 4 million $\mathrm{km}^{2}$ of wood.[1]

First used thousands of years ago by primitive humans to produce tools and fire, wood remains a very modern raw material for many important applications such as construction and/or decoration materials (timber, plywood, fibreboard), energy, cardboard, fibres and paper, additives and also, on much smaller scale, adhesives, inks, cleaning agents, cosmetics and perfumes.

Wood can be separated into two major families: hardwood produced by angiosperm trees that have broad leaves and reproduce flowers (e.g. oak, poplar, mulberry...), and softwood - produced by angiosperm or conifer trees (e.g. pines, spruce...). Both types of wood share common chemical constituents such as carbohydrates and lignin, but also have some significant differences, notably in the extractives.

The term extractives covers a large number of different chemicals, their contents and compositions varying among wood species, location in the tree (branch bases, leaves, roots, heartwood...), geographical area and season. The major wood extractives are terpenes and terpenoids, lignans, stilbenes, tannins, flavonoids and other aromatics, fats, waxes, fatty and other specific acids and alcohols, steroids and higher hydrocarbons.

In this article, we will focus on pine (softwood) and their extractives, and more specifically on terpenes and some of their unique derivatives used as speciality chemicals in fragrance applications. Firstly, among all softwood species, Pinus is one of the most widely distributed genera of trees belonging to the Pinacae family, which are one of the most important resources within the softwood population. Pines appeared between 190 and 136 million years ago in middle latitudes, and then extended their terri- 
tory from the polar region to the tropics. Today, pines are found in almost all latitudes and continents, the species depending on the geographical area and consequently the climate, which have an influence on the extractive contents and compositions (Table 1).

One of the main and most specific extractives from pine is oleoresin, its total amount generally representing between 0.2 to $1 \%$ based on dry wood. ${ }^{[2]}$ Mainly concentrated in the resin canals and the ray parenchyma cells, this latter, also called 'crude resin of the pine trees' or 'gum', is the viscous odorous balsam which flows onto the surface upon natural or artificial ('tapping industry' - vide infra) damage to the sapwood - between bark and the new wood as a protective barrier to seal the opening, and to reduce exposure to insects and micro-organisms. The resulting oleoresin contains a mixture of 'resin acids' (generally from 80 to $90 \%$ of oleoresin), and turpentine from which the term terpene originates (generally from 10 to $25 \%$ ).

Contrary to many plants also secreting terpenes such as citrus fruits, coriander, eucalyptus, lavender, roses, thyme, turpentine from pines is predominantly a mixture of unsaturated bicyclic monoterpene hydrocarbons with alpha-pinene, beta-pinene and/or delta-3-carene as the main constituents, their contents depending on the pine species. Other minor components are also present such as some other monoterpenes (limonene, camphene, terpinolene, beta-phellandrene, myrcene...), aromatics ( $p$-cymene), oxygenated compounds (terpineol, estragole, anethole...) and some higher molecular-weight terpenes (diterpenes, sesquiterpenes - longifolene, caryophyllene...). Table 1 summarizes the average compositions of the main pine species.

Historically, turpentine was first used as a solvent, disinfectant (behaving as white spirit from petrol). Today, biosourced terpe- nes, derived either from wood or from plants, are known to play an important role as either fragrance ingredients for perfumes, cosmetics, detergents or flavours for seasoning. Terpenes are also predicted to be more important in the future to compete with and replace some of the current fossil-based products. Therefore, considering the annual available volumes of turpentine (vide infra), the latter is expected to become one of the most strategic biosourced raw materials for the specific markets of fragrances and flavours, correlating with a shift of said industry away from fossil resources towards renewable materials. The renewable carbon (RC) content of a fragrance ingredient is calculated by dividing the number of carbon atoms from renewable sources by the total number of carbon atoms in the final product. For the F\&F industry, this currently entails predominantly the use of plant-based resources versus petrochemical sources. A material can be considered as renewable, as soon as its RC content exceeds $50 \%$, as defined by the ISO Norm 16128. ${ }^{[3]}$

As described earlier, the most traditional way to produce turpentine has been by tapping living pines followed by gum distillation. The first industrial exploitation was developed in the South-East of the United States of America, in the mid-19th century, where important forests of slash (Pinus Elliottii) and longleaf (Pinus Palustris) pines are located. Over a long period of time, this industry expanded into other continents (Europe, Asia, South America), and by the mid 20th century, gum turpentine (GT) became the main industrial source of turpentine. Despite improvement in techniques giving better recovery yields, collecting oleoresin remained too labour intensive, resulting in a reduction of this activity. Nowadays, annual GT volumes, mainly produced in Asia (mainly China and Indonesia) and South-

Table 1. Usual turpentine compositions per main pine species and main associated geographical areas.

\begin{tabular}{|c|c|c|c|c|c|c|c|c|}
\hline $\begin{array}{l}\text { Botanical } \\
\text { name }\end{array}$ & $\begin{array}{l}\text { Common } \\
\text { name(s) }\end{array}$ & $\begin{array}{l}\text { Main } \\
\text { geographical areas }\end{array}$ & $\begin{array}{l}\text { Alpha } \\
\text { Pinene } \\
(\%)\end{array}$ & $\begin{array}{l}\text { Beta } \\
\text { Pinene } \\
(\%)\end{array}$ & $\begin{array}{l}\text { delta- } \\
\text { 3-Carene } \\
(\%)\end{array}$ & $\begin{array}{l}\text { Beta } \\
\text { phellan- } \\
\text { drene }(\%)\end{array}$ & $\begin{array}{l}\text { Limonene } \\
(\%)\end{array}$ & $\begin{array}{l}\text { Others }^{a} \\
(\%)\end{array}$ \\
\hline $\begin{array}{l}\text { Pinus } \\
\text { Pinaster }\end{array}$ & $\begin{array}{l}\text { Maritime } \\
\text { pine }\end{array}$ & $\begin{array}{l}\text { France, Portugal, } \\
\text { Spain }\end{array}$ & $70-75$ & $10-20$ & $<1$ & $<1$ & $1-2$ & $<5$ \\
\hline $\begin{array}{l}\text { Pinus } \\
\text { Elliottii }\end{array}$ & Slash pine & $\begin{array}{l}\text { Brasil, Argentina, US, } \\
\text { South Africa, } \\
\text { Zimbabwe, Australia }\end{array}$ & $35-50$ & $30-45$ & $<1$ & $2-6$ & $0.5-2$ & $<5$ \\
\hline $\begin{array}{l}\text { Pinus } \\
\text { Massionana }\end{array}$ & $\begin{array}{l}\text { Masson } \\
\text { name }\end{array}$ & $\begin{array}{l}\text { China, } \\
\text { Vietnam }\end{array}$ & 80-90 & $3-8$ & $<0.5$ & $<1$ & $<1$ & $<5$ \\
\hline $\begin{array}{l}\text { Pinus } \\
\text { Merkusii }\end{array}$ & Merkus pine & Indonesia, Thailand & $80-85$ & $0.5-5$ & $8-12$ & $<0.5$ & $0.5-2$ & $<5$ \\
\hline $\begin{array}{l}\text { Pinus } \\
\text { Sylvestris }\end{array}$ & Scots pine & $\begin{array}{l}\text { Scandinavia, Russia, } \\
\text { Canada, North US }\end{array}$ & $45-60$ & $0.5-6$ & $15-30$ & $0.5-2$ & $1.5-5$ & $<5$ \\
\hline $\begin{array}{l}\text { Pinus } \\
\text { Kesiya }\end{array}$ & $\begin{array}{l}\text { Baguio / } \\
\text { Simao pine }\end{array}$ & $\begin{array}{l}\text { China, India, Thai- } \\
\text { land, Birmania, Laos, } \\
\text { Philippines }\end{array}$ & $70-85$ & $0.5-4$ & $<1$ & $<0.5$ & $0.5-2$ & $<5$ \\
\hline $\begin{array}{l}\text { Pinus } \\
\text { Caribaea }\end{array}$ & $\begin{array}{l}\text { Carribean } \\
\text { pine }\end{array}$ & South Africa, Kenya & $40-60$ & $0.5-2$ & $0.5-2$ & $20-30$ & $0.5-3$ & $<5$ \\
\hline $\begin{array}{l}\text { Pinus } \\
\text { Halepensis }\end{array}$ & Alep pine & $\begin{array}{l}\text { Greece, } \\
\text { North of Africa }\end{array}$ & $90-95$ & $0.1-2$ & $<0.5$ & $<1$ & $<1$ & $<5$ \\
\hline $\begin{array}{l}\text { Pinus } \\
\text { Brutia }\end{array}$ & & Turkey & $60-80$ & $0.5-15$ & $0.5-20$ & $<1$ & $1-5$ & $<5$ \\
\hline $\begin{array}{l}\text { Pinus } \\
\text { Radiata }\end{array}$ & $\begin{array}{l}\text { Monterey } \\
\text { pine }\end{array}$ & $\begin{array}{l}\text { Chile, New Zealand, } \\
\text { Australia, Kenya, } \\
\text { Spain, West US }\end{array}$ & $20-30$ & $45-60$ & $<1$ & $<1$ & $<1$ & $<5$ \\
\hline
\end{tabular}


America (mainly Brazil), represent around 160,000 $\mathrm{T}$ and are expected to continue to decline in the future.

In parallel, other industries started in the late 19th - early 20th centuries to also produce turpentine from Pinacae. For instance, we can cite wood turpentine, produced from solvent extraction of softwood stumps, and, in particular, crude sulphate turpentine, a by-product of the softwood kraft pulping process. The latter, also called CST, was originally recovered for safety concerns and then burned within the mills. However, this source of turpentine gained in relevance as the interest in the kraft pulping industry increased, causing more attention from this industry to upcycle it for more valuable uses. Today, CST is the most important available source of turpentine, with annual amounts of around 190,000 T produced.

The kraft pulping industry, developed in the late 19th century in Germany, is the most important chemical conversion industry of wood. The purpose was to chemically separate all the woody components, aiming first at producing wood pulp (around 50\% of yield) which means almost pure cellulose fibres used for paper, tissues, cardboards, additives... The resulting dissolved lignin is mainly used for energy recovery (allowing this industry to be almost self-sufficient). This process, when applied to softwoods, also allows the upcycling of some by-products - extractives such as tall oil (mixture of fatty and rosin acids, and some neutrals like sterols) and CST.

With a consumption of around 320 million tons of wood in 2019 , kraft pulping is today considered to be the largest biorefinery industry and is expected to continue its significant growth due to increased demands for sustainable biobased products such as packaging due to the booming demand of e-commerce. Consequently, CST is gaining more and more interest from the market based on terpenic derivatives from pine.

During the kraft process, which involves the use of sodium hydroxide and sodium sulphide liquors with wood chips, at reaction temperatures ranging from 140 to $180{ }^{\circ} \mathrm{C}$ over a time period of 1 to $4 \mathrm{~h}$, most of terpenes are vaporized with some other low-boiling compounds that have been generated such as dimethylsulphide, dimethyldisulphide and sent to a condensing system. Condensates are then decanted, and the resulting organic phase, CST, is obtained. Whereas similar monoterpene compositions and contents are found between GT and CST recovered from the same pine species, the presence of residual sulphide compounds and some heavy terpenic compounds in CST (Table 2) require specific, expensive and productivity-impacting purification stages before being equivalent to GT.

\section{Results \& Discussion}

\subsection{CST Refining}

Crude sulphate turpentine (CST) from paper mills using the kraft process is a commercially important source of $\alpha$ - and $\beta$-pinene, which are renewable, biomass-derived raw materials used in the synthesis of aroma/flavouring products.

The first phase of CST refining consists of removing the light and heavy compounds, respectively, by distillation. The 'head fraction' (the most volatile compounds) contain mostly volatile sulphurous compounds ( 2\% of CST) such as methyl mercaptan, dimethyl sulphide and dimethyl disulphide. Once the head fractions have been removed, distillation is continued and intermediate cuts (distillation heart) containing the pinenes are collected. The distillation residues containing heavy products including sulphurous terpenes are removed.

The head fractions and the heavy products are sent to an incinerator. Sulphur dioxide and trioxide are then captured in a scrubbing tower to be transformed into sulphites and sulphates.

Although turpentine is largely desulphurised during the above stripping steps, many $\alpha$ - and $\beta$-pinene sources require subsequent transformations giving further desulphurisation in order to obtain acceptable sulphur levels (less than $500 \mathrm{ppm}$ )

Refining is followed by a continuous distillation under reduced pressure, giving the very efficient separation of the main terpenic compounds $\alpha$-pinene $(60-70 \%), \beta$-pinene $(20-25 \%)$, limonene/phellandrene (3-10\%), and methyl chavicol and anethole/caryophyllene (1-2\%). The $\alpha$ - and $\beta$-pinene are then used as raw materials (Scheme 1). ${ }^{[4]}$

\subsection{Presentation of the Major Intermediates of $\alpha$-Pinene Chemistry}

An overview of intermediates produced from $\alpha$-pinene $(\mathbf{1})$ is given in Scheme 2.

\subsubsection{3,7-Dimethyl-1,6-octadiene}

3,7-Dimethyl-1,6-octadiene (2) is currently obtained in two steps from $\alpha$-pinene (1). The first step is a selective hydrogenation of $\alpha$-pinene (1) into cis-pinane (7) followed by pyrolysis conducted at $550-600{ }^{\circ} \mathrm{C}$. The hydrogenation step can be catalysed by supported nickel ${ }^{[5]}$ or ruthenium catalysts ${ }^{[6]}$ (Scheme 3$)$. If the $\alpha$-pinene (1) used is optically active, the resulting pinane (7) is also optically active. ${ }^{[7]}$ It is important to have a very high cis-isomer selectivity during hydrogenation to limit the formation of the by-product 5,7-dimethyl-1,6-octadiene (8). ${ }^{[8]}$

Table 2. Usual CST compositions per main geographical areas.

\begin{tabular}{|c|c|c|c|c|c|c|c|}
\hline $\begin{array}{l}\text { CST } \\
\text { geographical } \\
\text { origins }\end{array}$ & $\begin{array}{l}\text { Alpha Pinene } \\
(\%)\end{array}$ & $\begin{array}{l}\text { Beta Pinene } \\
(\%)\end{array}$ & $\begin{array}{l}\text { delta-3-Carene } \\
(\%)\end{array}$ & Limonene (\%) & $\begin{array}{l}\text { Heavier terpe- } \\
\text { nic compounds } \\
\text { (sesquiter- } \\
\text { penes, diter- } \\
\text { penes, terpenic } \\
\text { alcohols, rosin } \\
\text { and fatty acids) } \\
(\%)\end{array}$ & $\begin{array}{l}\text { Dimethyl- } \\
\text { sulfide } \\
\left(\mathrm{CH}_{3} \mathrm{SCH}_{3}\right) \\
\text { usual propor- } \\
\text { tion within sul- } \\
\text { fur compounds } \\
(\%)\end{array}$ & $\begin{array}{l}\text { Dimethyl- } \\
\text { disulfide } \\
\left(\mathrm{CH}_{3} \mathrm{SSCH}_{3}\right) \\
\text { usual propor- } \\
\text { tion within sul- } \\
\text { fur compounds } \\
(\%)\end{array}$ \\
\hline $\begin{array}{l}\text { North and } \\
\text { East of EU }\end{array}$ & $35-55$ & $3-12$ & $15-30$ & $1-6$ & $5-25$ & $>60 \%$ & $<10 \%$ \\
\hline $\begin{array}{l}\text { South West } \\
\text { of EU }\end{array}$ & $50-65$ & $12-22$ & $0.1-3$ & $0.1-4$ & $5-20$ & $>60 \%$ & $<10 \%$ \\
\hline $\begin{array}{l}\text { South East } \\
\text { of US }\end{array}$ & $50-70$ & $15-25$ & $0.1-1.5$ & $0.1-3$ & $3-15$ & $>60 \%$ & $<10 \%$ \\
\hline
\end{tabular}




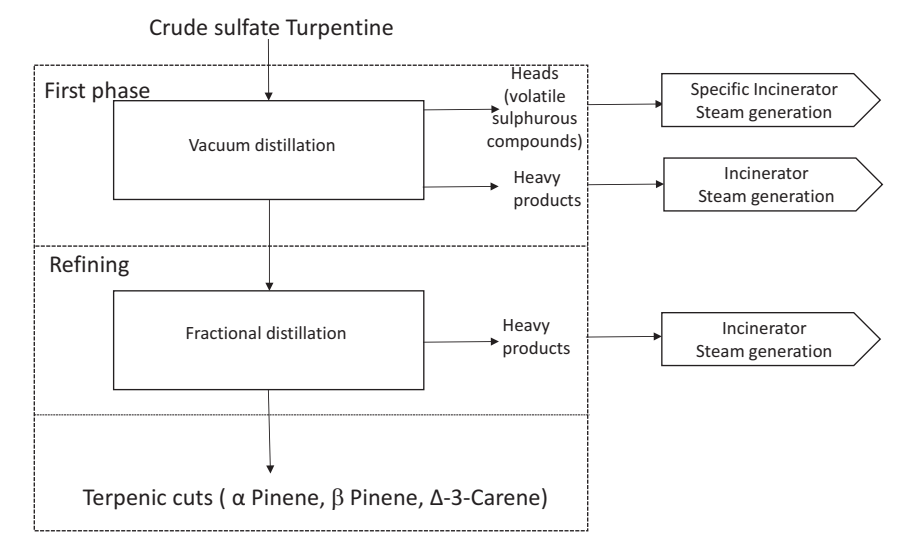

Scheme 1. CST refining.

\subsubsection{Campholenic Aldehyde}

Campholenic aldehyde (3) is currently obtained by a rearrangement of epoxy- $\alpha$-pinane (9). Epoxidation of $\alpha$-pinene (1) is performed with peracetic acid. The use of a stoichiometric quantity of sodium bicarbonate neutralises the acetic acid and avoids the opening of epoxy- $\alpha$-pinane (9) into sobrerol. The stereospecific rearrangement of epoxy- $\alpha$-pinene (9) is usually carried out with zinc bromide and leads to a mixture of campholenic aldehyde (3) and pinocamphone (10) (Scheme 4). ${ }^{[9]}$ The epoxidation of $(+)-\alpha$-pinene leads to $(+)$-cis-epoxy- $\alpha$-pinane (9) and after rearrangement to (-)-campholenic aldehyde (3). ${ }^{110,11]}$

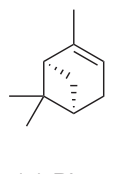

(+)-Pinne

(1)

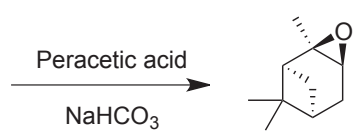

$(+)$-cis-epoxypinane

(9)

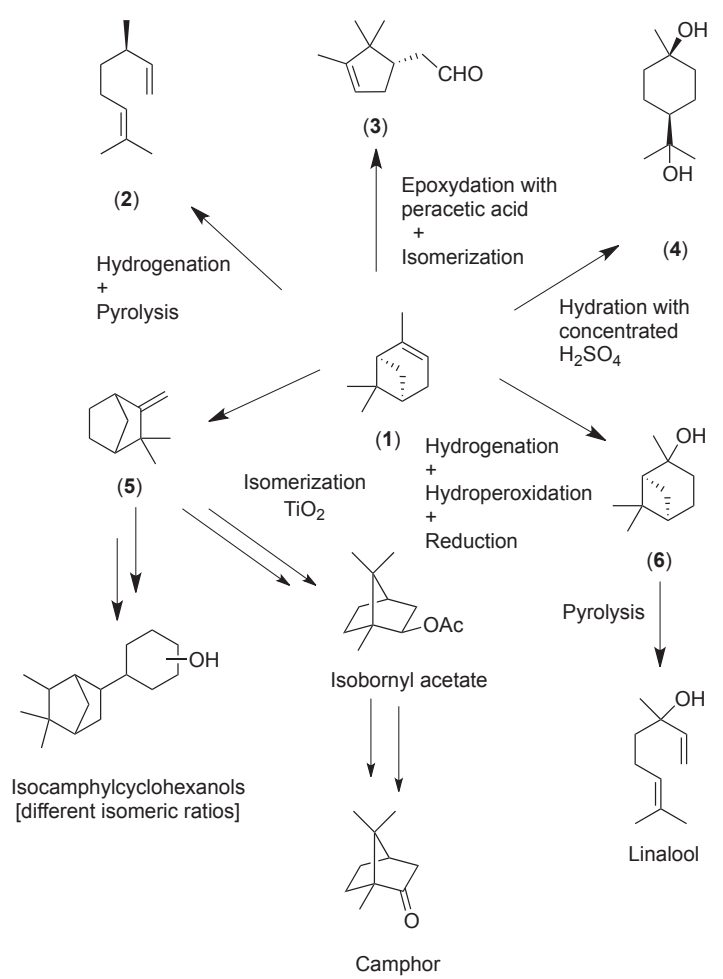

Scheme 2. Synthesis of 3,7-dimethyl-1,6-octadiene (2), campholenic aldehyde (3), cis-terpine hydrate (4), camphene (5) and pinanol (6) from $\alpha$-pinene (1).

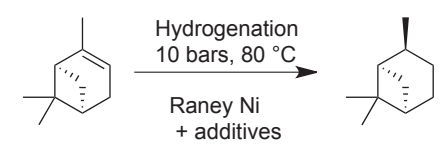

$(+)-\alpha-$ Pinene

(1)

$$
(+) \text {-cis-Pinane }
$$$$
\text { (7) }
$$

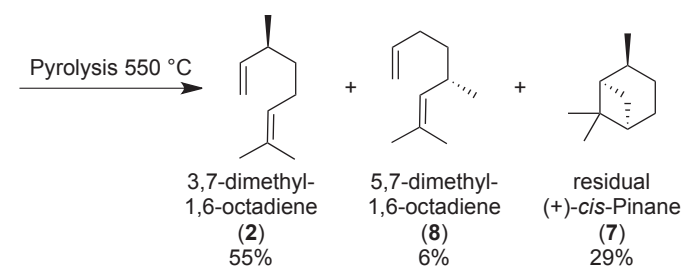

Scheme 3. Synthesis of cis-pinane (7) and 3,7-dimethyl-1,6-octadiene (2) from $\alpha$-pinene (1).

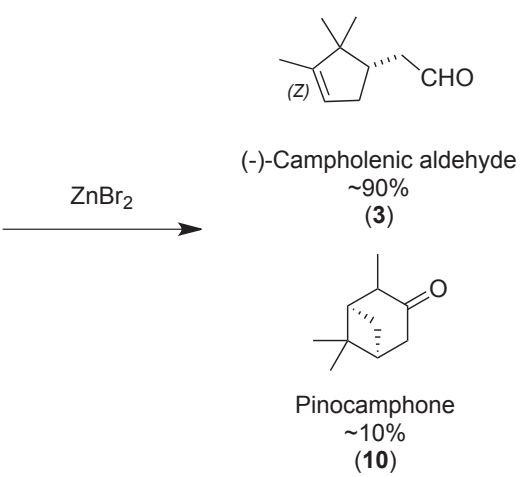

Scheme 4. Synthesis of campholenic aldehyde (3) and pinocamphone (10) from $\alpha$-pinene (1).

Campholenic aldehyde (3) is the precursor of a wide range of renewable synthetic sandalwood ingredients obtained by aldol-condensation, alkylation and reduction reactions (Scheme 5). [12]

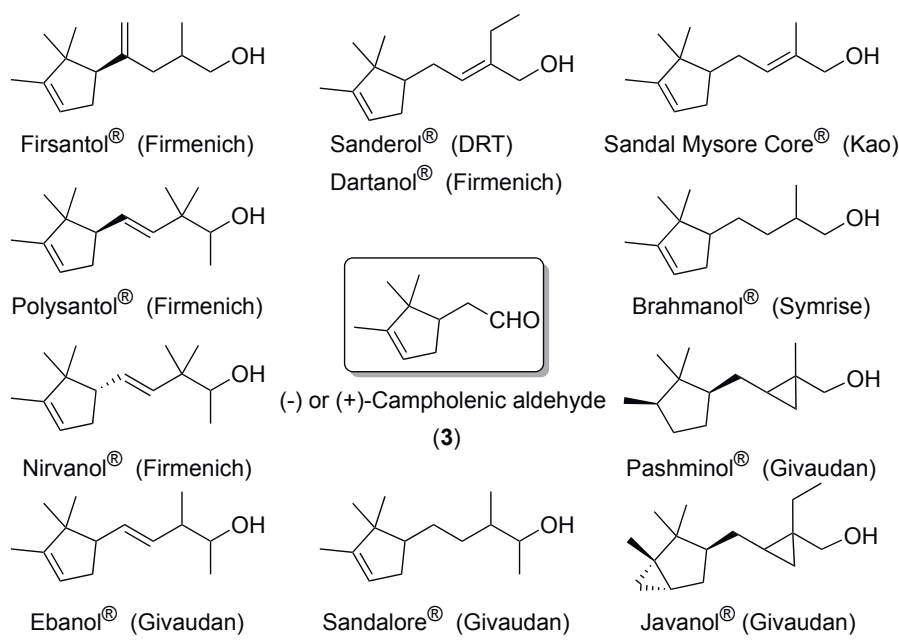

Scheme 5. Sandalwood odorants from campholenic aldehyde (3)

\subsubsection{Terpin Hydrate}

Hydration of $\alpha$-pinene (1) in the presence of sulfuric acid and a surfactant leads to crystalline cis-terpine (4). The surfactant and the acid phase are recycled. Easy removal of dehydration coproducts (unreacted $\alpha$-pinene (1), dipentene, terpinolene, $\gamma$-terpinene, $\alpha$-terpinene and cineols) is performed by filtration of the solid 
product. Crystalline cis-terpine (4) is the raw material for terpineol (11), obtained via mild dehydration with phosphoric acid.[13] The most common commercial grade of terpineol is a mixture of $\alpha, \beta$, and $\gamma$ isomers (11) (Scheme 6).

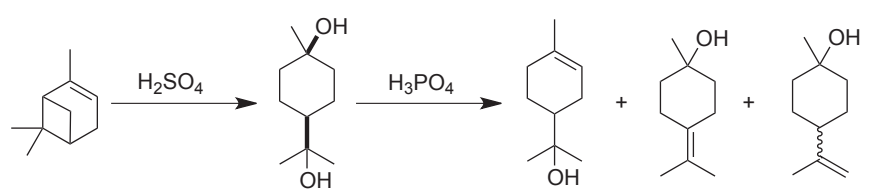

Pinene (1) cis-Terpine (4)

$\alpha$-Terpineol $\gamma$-Terpineol $\quad \beta$-Terpineol $21 \%$ $12 \%$ Terpineol isomers (11)

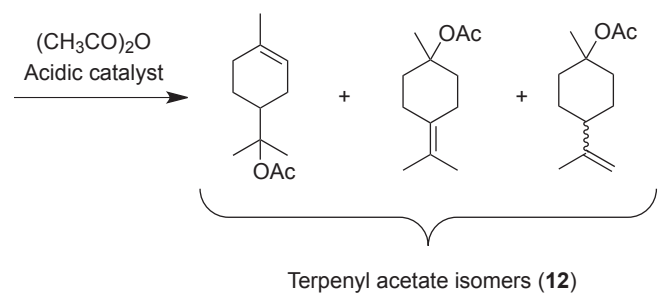

Scheme 6. Synthesis of terpineol isomers (10) and terpenyl acetate isomers (11) from $\alpha$-pinene (1).

It is also possible to hydrate $\alpha$-pinene (1) or turpentine directly into terpineols (11) without going through the cis-terpine diol step. The reaction is generally carried out in aqueous acetic acid and is catalysed by a mineral acid. Under these conditions, the obtained terpineols contain mainly the $\alpha$-isomer. ${ }^{[14]}$

Terpineol (11) is readily acetylated to its corresponding acetate (12) in the presence of acetic anhydride. Hydrogenation of terpineols (11) over Raney nickel leads to menthanol which in turn can be acetylated to menthanyl acetate.

\subsubsection{Camphene}

Camphene (5) is produced by the reaction of $\alpha$-pinene (1) with a specific $\mathrm{TiO}_{2}$ catalyst. Preparation of this catalyst has a great influence on the product composition and yield. Camphene (5) is used to prepare a number of fragrance compounds. Condensation with acetic acid produces isobornyl acetate, a fragrance ingredient with a pine odour. Isobornyl acetate is useful for producing isoborneol by saponification. Dehydrogenation of isoborneol produces camphor, an important product used in religious ceremonies in Asian countries.

Of the synthetic sandalwood odorants, isocamphylcyclohexanols have found wide commercial application. These odorants are obtained by a Lewis acid-catalysed condensation of camphene with phenol (or guaiacol) followed by catalytic hydrogenation (Scheme 2).

\subsubsection{Pinanol}

Cis/trans pinanol (6) can be prepared by an oxidation with oxygen of $c i s$-pinane in the presence of a radical initiator followed by reduction with sodium sulphite. Thermolysis of cis/trans pinanol gives linalool (Scheme 2).

\subsection{Presentation of the Major Intermediates of $\beta$-Pinene Chemistry}

An overview of intermediates produced from $\beta$-pinene (13) is given in Scheme 7.

\subsubsection{Nopol}

(-)-Nopol (14) is obtained via a Prins reaction between paraformaldehyde and $\beta$-pinene (13) at high temperature. ${ }^{[15]}$

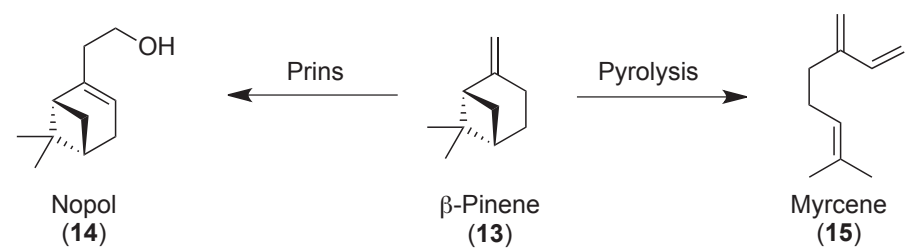

Scheme 7. Synthesis of nopol (14) and myrcene (15) from $\beta$-pinene (13).

The main derivatives of nopol (14) are nopyl acetate (16), produced by reaction with acetic anhydride and cis-dihydronopol (17), obtained by hydrogenation with heterogeneous cat such as $\mathrm{Pd}$, Ni or Ru and used in the pharmaceutical industry (Scheme 8).

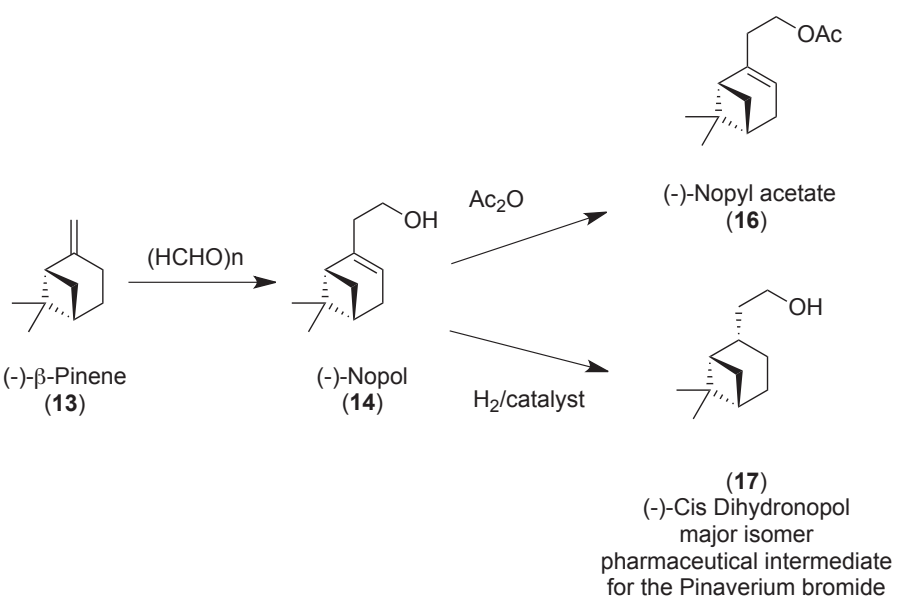

Scheme 8. Synthesis of nopyl acetate (16) and cis-dihydronopol (17) from $\beta$-pinene (13).

\subsubsection{Myrcene}

Myrcene (15) is the major intermediate by volume in the chemistry of $\beta$-pinene (13). It is obtained by pyrolysis of $\beta$-pinene (13) at temperatures ranging between 550 and $600{ }^{\circ} \mathrm{C}$. Pyrolysis produces a mixture of myrcene $(\mathbf{1 5}, 75-80 \%),(-)$-limonene $(\mathbf{1 8}$, 9-10\%) and pseudolimonene $(\mathbf{1 9},<8 \%)$ (Scheme 9). ${ }^{[16]}$

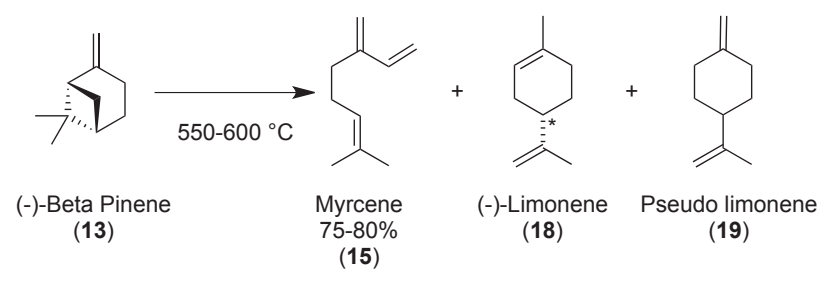

Scheme 9. Synthesis of myrcene (15) from $\beta$-pinene (13).

This 75\% myrcene (15) quality is used without further purification in the synthesis of other perfumery compounds. The main perfumery derivatives of myrcene (15) are Anthamber/Iso E Super $^{\circledR}$, Sylvamber $^{\circledR}(\mathbf{2 2})$, geraniol and its acetate, nerol and its acetate, citronellol and its acetate, menthol (Takasago) and DielsAlder adducts with acrolein (Myrac aldehyde ${ }^{\circledR} /$ Mircenal $^{\circledR}$ ), and Cyclomyral $^{\circledR} /$ Melafleur $^{\circledR} /$ Cyclozonal $^{\circledR}$.

The $75 \%$ myrcene (15) quality can be distilled in the presence of polymerisation inhibitors under reduced pressure and moderate 
temperature for perfumery grade $(90 \%)$. Due to the susceptibility of the diene motif, myrcene (15) storage must be of short duration ( $\leq 6$ months).

\subsection{Special Focus on Dihydromyrcenol (20), Florsantol ${ }^{\circledR}(21)$, Iso E Super ${ }^{\circledR}$ (22), Helvetolide ${ }^{\circledR}$ (23) and Romandolide $^{\circledR}$ (24)}

\subsubsection{Dihydromyrcenol (20)}

Dihydromyrcenol is obtained from 3,7-dimethyl-1,6-octadiene (2) either by addition of formic acid and subsequent saponification of dihydromyrcenyl formate ${ }^{[17]}$ or by direct hydration with concentrated aqueous sulphuric acid at low temperature (Scheme 10). ${ }^{[18]}$

This ingredient is one of the biggest fragrance volume drivers.

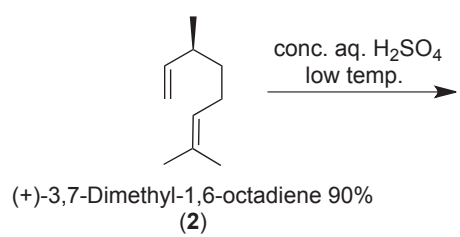

(2)

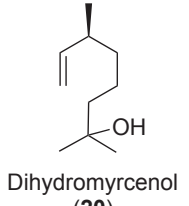

(20)
Scheme 10. Synthesis of dihydromyrcenol (20) from 3,7-dimethyl1,6-octadiene (2).

\subsubsection{Florsantol $^{\circledR}$}

The addition of methanol to 3,7-dimethyl-1,6-octadiene (2) provides methoxycitronellene (25). The reaction is catalysed by concentrated sulfuric acid. ${ }^{[19]}$ The best selectivity is obtained at partial conversion and remaining 3,7-dimethyl-1,6-octadiene is recycled by distillation.

Epoxidation of the residual double bond is carried out either with peracetic acid alone, ${ }^{[20]}$ peracetic acid generated in situ from the urea/hydrogen peroxide + acetic anhydride complex ${ }^{[21]}$ or with hydrogen peroxide in presence of phosphotungstic acid and a phase transfer catalyst. ${ }^{[22,23]}$ Reduction of the epoxide (26) is performed either by hydrogenation or with alkali hydrides. The main hydrogenation catalysts are $\mathrm{Pd} / \mathrm{C},{ }^{[24,25]}$ Raney nickel in the

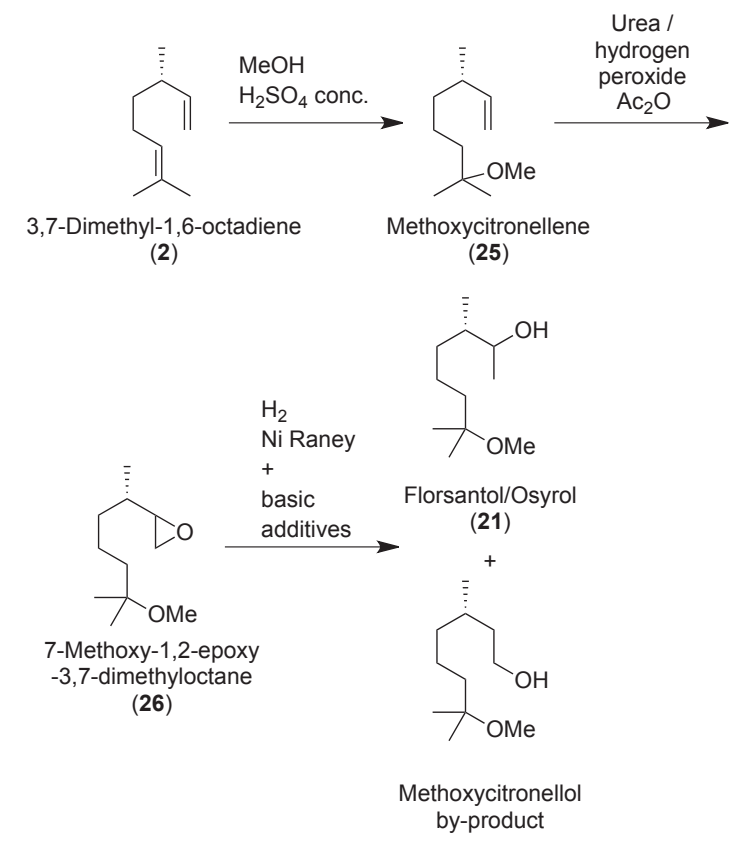

Scheme 11. Synthesis of methoxycitronellene (25), 7-methoxy1,2-epoxy-3,7-dimethyloctane (26) and Florsantol ${ }^{\circledR}(\mathbf{2 1})$ from 3,7-dimethyloctadiene (2). presence of a base (sodium carbonate or triethylamine) in order to promote the formation of the desired secondary alcohol, Florsantol $^{\circledR}(\mathbf{2 1})^{[26]}$ and finally, homogeneous ruthenium complex $\mathrm{Cp} * \mathrm{RuCl}(\mathrm{COD})-($ diphenylphosphino)ethylamine) with $\mathrm{KOH}$ as described by Ikariya. ${ }^{[27]}$ Alkali hydrides described in literature are potassium borohydride ${ }^{[22,23]}$ or Vitride ${ }^{\circledR}$ (Scheme 11). ${ }^{[21]}$

\subsubsection{Cyclademol $^{\circledR}$}

In $1966 \mathrm{~J}$. H. Blumenthal from IFF patented compounds 27, 28, 29 and 30 (Scheme 12, Scheme 13). He recognized the value of those new ingredients for the elaboration of fragrances. ${ }^{[28]}$ The treatment of 3,7-dimethyl-1,6-octadiene (2) with formic acid in presence of a catalytic amount of $\mathrm{BF}_{3} \mathrm{OEt}_{2}$ led to the formation of dihydromyrcenyl formate. A rearrangement occurred at higher temperature to form cyclic formate $\mathbf{2 7}$ as a major product, known as Aquamate ${ }^{\circledR}$ (DRT) or Aphermate ${ }^{\circledR}$ (IFF), which has a herbal, woody, ozonic, fruity smell. Saponification of Aphermate ${ }^{\circledR}$ (27) produced Cyclademol ${ }^{\circledR}(\mathbf{2 8})$. Rosamusk $^{\circledR}(\mathbf{2 9})$ was obtained from 3,7-dimethyl-1,6-octadiene (2) using acetic acid and a catalytic amount of $\mathrm{BF}_{3} \mathrm{OEt}_{2}$. It has a rosé-fruity odour with a floral, geranium, musky fruity note (Scheme 12). In 1972 Hall and then in 1973 H. R. Ansari found that the mechanism and stereospecificity of this rearrangement depend on the stereochemistry of the starting 3,7-dimethyl-1,6-octadiene (2). ${ }^{[29,30]}$
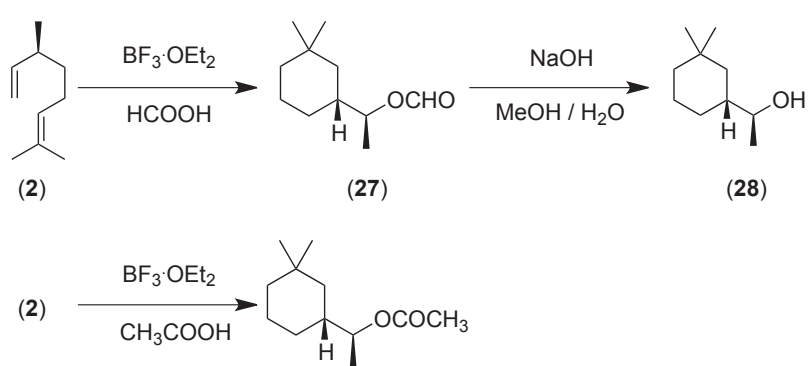

(29)

Scheme 12. Synthesis of Aquamate ${ }^{\circledast}(\mathbf{2 7})$, Cyclademol $^{\circledast}(\mathbf{2 8})$, and Rosamusk $^{\circledR}$ (29) from 3,7-dimethyl-1,6-cyclooctadiene (2). ${ }^{[2,31]}$

Treatment of Cyclademol ${ }^{\circledR}$ (28) with copper chromium catalyst gave ketone $\mathbf{3 0}$ which has a herbal note odour with woody, cedar leaf, minty nuances. It was introduced into perfumery as $\operatorname{Herbac}^{\circledR}$ (IFF) or Thuyac ${ }^{\circledR}$ (Firmenich) (Scheme 13). ${ }^{[28]}$

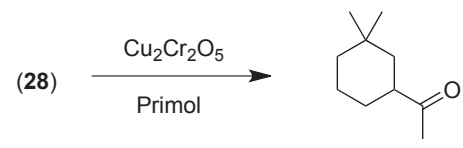

(30)

Scheme 13. Synthesis of $\operatorname{Herbac}^{\circledR}(\mathbf{3 0})$ from Cyclademol $^{\circledR}$ (28). ${ }^{[32]}$

In 1990, Giersch and Schulte-Elte used Cyclademol ${ }^{\circledR}$ (28) as starting material to create an exceptional acyclic, renewable musk, Helvetolide ${ }^{\circledR}(\mathbf{2 3})$, the first member of this family. ${ }^{[33]}$ Its synthesis started with the treatment of alcohol $\mathbf{2 8}$ with isobutylene oxide (31) in presence of $\mathrm{BF}_{3} \mathrm{OEt}_{2}$ to form Helvetol ${ }^{\circledR}(\mathbf{3 2})$. Esterification with propionic anhydride gave Helvetolide ${ }^{\circledR}(\mathbf{2 3})$ (Scheme 14). The odour of its dextrorotatory isomer is more powerful musky-floral than that of its levorotatory isomer.

In 2000, Williams investigated ester derivatives of Cyclademol ${ }^{\circledR}$ (28) in the search for new musky ingredients. He replaced the gem-dimethyl moiety of Helvetolide ${ }^{\circledR}(\mathbf{2 3})$ with an ester group to afford Romandolide ${ }^{\circledR}$ (24) (Scheme 15). ${ }^{[34]}$ Despite being less 
(28)

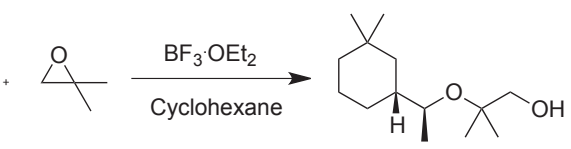

(31)

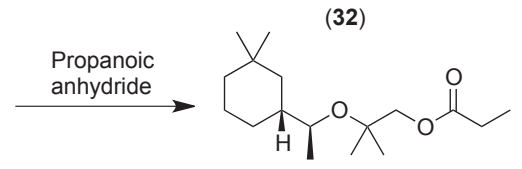

(23)

Scheme 14. Synthesis of Helvetolide ${ }^{\circledR}(\mathbf{2 3})$ from Cyclademol $^{\circledR}(28) \cdot{ }^{[33]}$

fruity and less Ambrette than Helvetolide ${ }^{\circledR}(\mathbf{2 3})$, Romandolide ${ }^{\circledR}$ (24) was easier to manufacture and became a widely used musk. Similarly to Helvetolide ${ }^{\circledR}(\mathbf{2 3})$, the $(1 S, 3 R)$-enantiomer of Romandolide $^{\circledR}(\mathbf{2 4})$ was reported to be the most powerful isomer. ${ }^{[34]}$

(28)

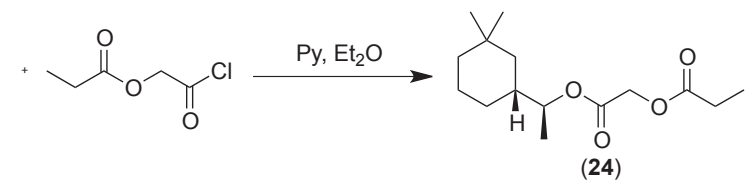

Scheme 15. Synthesis of Romandolide ${ }^{\circledR}(\mathbf{2 4})$ from Cyclademol $^{\circledR}(\mathbf{2 8})$.

In 2002, Kraft and co-workers patented a new musk by replacing the ester propanoate moiety of Helvetolide ${ }^{\circledR}(\mathbf{2 3})$ with a cyclopropanecarboxylate moiety to afford Serenolide ${ }^{\circledR}(33)$ (Scheme 16). ${ }^{[35]}$

(32)

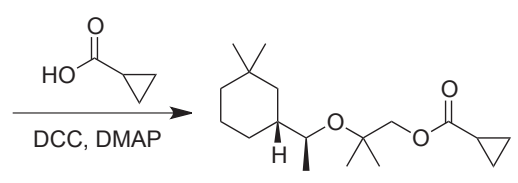

(33)

Scheme 16. Synthesis of Serenolide ${ }^{\circledR}(33)$ from Helvetol ${ }^{\circledR}(32)$.

In 2004 Britten-Kelly and co-workers from IFF reported the synthesis of a new musk from Cyclademol ${ }^{\circledR}(\mathbf{2 8})$ and diethyl malonate (34) in one step. ${ }^{[36]}$ The compound was introduced in the perfumery palette as Edenolide ${ }^{\circledR}(\mathbf{3 5})$ and the racemic form as Applelide ${ }^{\circledR}$. The odour is musky, animalic but weaker compared to Helvetolide ${ }^{\circledR}$ (23) (Scheme 17).

(28)

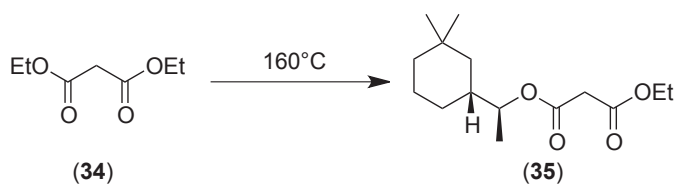

Scheme 17. Synthesis of Edenolide (35) from Cyclademol ${ }^{\circledR}$ (28). ${ }^{[37]}$

\subsubsection{Iso E Super/Sylvamber (22)}

Iso E Super ${ }^{\circledR}(\mathbf{2 2})$ (DRT product: Anthamber ${ }^{\circledR}$ ) is a very important renewable perfumery ingredient because of its woody amber note . It was discovered in the mid-1970s by IFF. ${ }^{[38]}$ It was obtained via a Diels-Alder reaction between myrcene (15) and 3-methylpent-3-en-2-one (36). The reaction was catalysed by aluminium chloride and followed by an acid-catalysed cyclisation of the adduct obtained Precyclemone $\mathrm{E}^{\circledR}$ (37). This cyclisation via a carbocation was not very selective and occurred with secondary isomerisations so that the final product was obtained as a complex mixture of isomeric ketones (22a, 22b, 22c, 22d, 22e and 22f) at different concentrations (Scheme 18). There were six major isomers which were evaluated by GC-olfactometry. They were then also isolated, purified and characterised after fractional distillation, oximation, fractional crystallisation and then hydrolysis to determine their structure. ${ }^{[39]}$ In this way, Givaudan's researchers determined that the 22a isomer (5-6\% of Iso E Super ${ }^{\circledR}$ ) had an olfactory detection threshold of $5 \mathrm{pg} / \mathrm{l}$ of air and was 100,000 times more powerful than the major 22b isomer (olfactory detection threshold $500 \mathrm{ng} / \mathrm{l}$ of air, isomer present at about $40 \%$ in Iso E Super $\left.{ }^{\circledR}\right) .{ }^{[40,41]}$ A total enantioselective synthesis of this 22a isomer, $(+)$-Arborone ${ }^{\circledR}$, was proposed by E.J. Corey and Sungwoo Hong. ${ }^{[42]}$

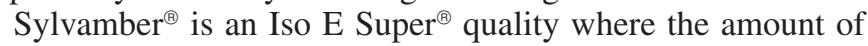
isomer 22a is increased by a factor of 3.[43]

\section{Conclusion}

Even if the pulp and paper industry put a lot of effort in developing a sustainable process by recycling or producing bio-fuel from their waste products, part of their guaranteed waste, namely crude sulphate turpentines (CST) could not, however, be valorised properly. Fragrance chemists started to use this upcycled, biomass-derived waste as raw material towards renewable perfume ingredients. Two main products can be isolated, $\alpha$-pinene and the $\beta$-pinene. From these two raw materials, several fragrance ingredients are currently produced on industrial scale.

The CST-derived perfumery ingredient portfolio has played a substantial role in contributing to an increase in the biomass-derived, and thus renewable carbon content of the perfumery palette. With increasing pressure on CST and/or GT resources, also observed for other biomass supplies, the use of alternative renewable carbon sources is likely to gather in importance in the coming years. These alternative carbon sources could include in the future recaptured carbon or recycled fossil-derived carbon, which at the moment rely on less established sourcing and/or production processes.

\section{Acknowledgements}

We thank our coworkers Dr. Christian Chapuis, Dr. Alec Birkbeck, Dr. Gilles Oddon and Dr. Alvin Williams for proof-reading the article. We acknowledge continous financial support from Firmenich and DRT.

Received: July 12, 2021

[1] Évaluation des ressources forestières mondiales 2020 - Principaux résultats. Rome., Organisation des Nations Unies pour l'alimentation et l'agriculture, 2020, https://doi.org/10.4060/ca8753fr.

[2] D. Fengel, G. Wegener, in 'WOOD: Chemistry - Ultrastruture - Reactions', Ed. W. de Gruyter, 1989.

[3] 'Cosmetics - Guidelines on technical definitions and criteria for natural and organic cosmetic ingredients - Part 2: Criteria for ingredients and products (ISO/DIS Standard No. 16128-2)', International Organization for Standardization, 2017, retrieved from https://www.iso.org/standard/65197. html.

[4] J. O. Bledsoe Jr., in 'Kirk-Othmer Encyclopedia of Chemical Technology'.

[5] L. A. Canova, Patent No. US4018842A, 1977.

[6] M. Duval, S. Navarre, G. Sagorin, A. Denicourt-Nowicki, A. Roucoux, ACS Sustainable Chem. Eng. 2020, 8, 5985, https://doi.org/10.1021/acssuschemeng.0c00650.

[7] J. P. Bain, Patent No. US3277206, 1966.

[8] A. Stolle, B. Ondruschka, H. Hopf, Helv. Chim. Acta 2009, 92, 1673, https://doi.org/10.1002/hlca.200900041.

[9] C. Chapuis, R. Brauchli, Helv. Chim. Acta 1992, 75, 1527, https://doi.org/10.1002/hlca.19920750507.

[10] B. Arbuzov, Ber. Dtsch. Chem. Ges. B 1935, 68B, 1430-1435.

[11] J. B. Lewis, G. W. Hedrick, J. Org. Chem. 1965, 30, 4271, https://doi.org/10.1021/jo01023a064.

[12] P. Dupau, Helv. Chim. Acta 2018, 101, 1, https://doi.org/10.1002/hlca.201800144. 
Step 1
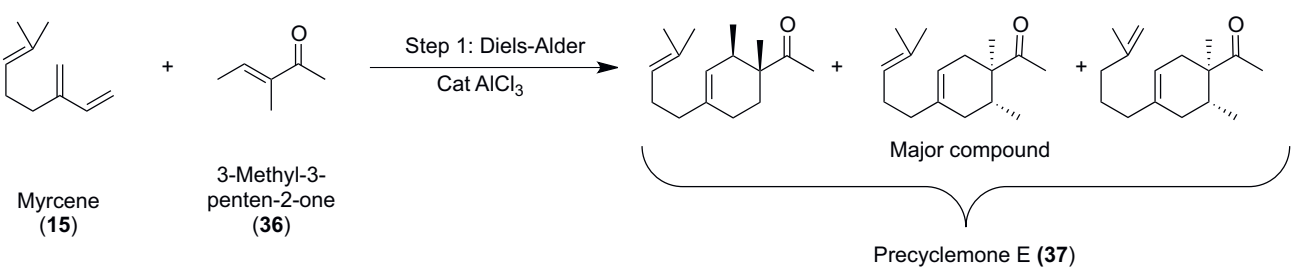

Scheme 18. Iso E Super (22) synthesis.

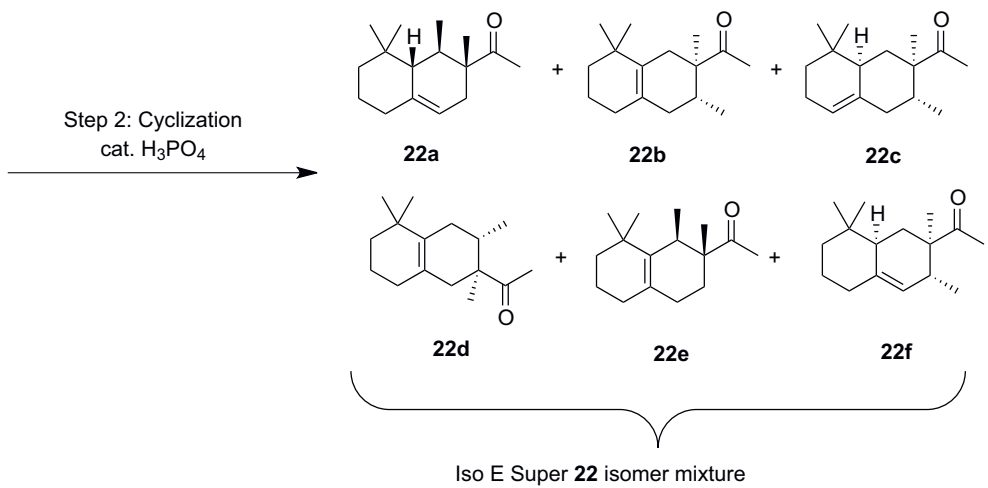

[13] J. E. Sapp, W. F. Gillespie, P. A. McKim, Patent No. US2628258, 1953.

[14] V. K. Sethi, S. S. Andotra, R. K. Thappa, K. L. Dhar, Patent No. IN195195B, 2005.

[15] J. P. Bain, A. H. Best, C. K. Clark, B. L. Hampton, J. Am. Chem. Soc. 1946, 68, 638, https://doi.org/10.1021/ja01208a032.

[16] L. A. Goldblatt, S. Palkin, Patent No. US2420131, 1947.

[17] J. H. Blumenthal, Patent No. GB1160396, 1969.

[18] J. Ibarcq, B. Lahourcade, Patent No. FR2597861A1, 1987.

[19] R. L. Webb, Patent No. US2902510, 1959.

[20] J. D. C. Wilson, II, Patent No. US2838524, 1958.

[21] R. Parthasarathy, N. Sulochana, Flavour and Fragrance J. 2016, 31, 120, https://doi.org/10.1002/ffj.3287.

[22] W. Wang, H. Qiu, B. Zhao, Y. Gao, H. Yao, Patent No. CN101906024A, 2010

[23] W. Wang, Q. Liu, Patent No. CN105001061A, 2015.

[24] P. S. Dragovich, T. J. Prins, R. Zhou, J. Org. Chem. 1995, 60, 4922, https://doi.org/10.1021/jo00120a042.

[25] M. Duval, V. Deboos, A. Hallonet, G. Sagorin, A. Denicourt-Nowicki, A Roucoux, J. Catal. 2021, 396, 261, https://doi.org/10.1016/j.jcat.2021.02.027.

[26] B. N. Jones, H. R. Ansari, B. G. Jaggers, J. F. Janes, Patent No. DE2255119A1, 1973.

[27] M. Ito, M. Hirakawa, A. Osaku, T. Ikariya, Organometallics 2003, 22, 4190, https://doi.org/10.1021/om034006j.

[28] J. H. Blumenthal, Patent No. FR1543320, 1968.

[29] J. B. Hall, L. K. Lala, J. Org. Chem. 1972, 37, 920, https://doi.org/10.1021/jo00971a026.

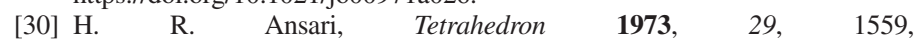
https://doi.org/10.1016/S0040-4020(01)83397-4.

[31] D. Ying, C. Hu, W. Weng, G. Luo, W. Chen, X. Lin, J. Wu, Patent No. CN111423323A, 2020

[32] S. Xu, M. Fang, Patent No. CN109836321A, 2019.

[33] W. K. Giersch, K. H. Schulte-Elte, Patent No. EP472966A1, 1992.
[34] A. S. Williams, Patent No. WO2000014051A1, 2000.

[35] P. Kraft, R. Cadalbert, Patent No. EP1262474A1, 2002.

[36] J. O. Bledsoe, M. Britten-Kelly, M. A. Sprecker, R. P. Belko, M. Pawlak, M. G. Monteleone, Patent No. EP1398366A1, 2004.

[37] A. T. Levorse, Jr., C. M. Smith, R. A. Weiss, Patent No. US7563925B1, 2009.

[38] J. B. Hall, J. M. Sanders, Patent No. US3929677A, 1975.

[39] M. B. Erman, M. J. Williams, P. Whelan, C. G. Cardenas, Perfumers \& Flavorist 2001, 26, 16-21.

[40] C. Nussbaumer, G. Fráter, P. Kraft, Helv. Chim. Acta 1999, 82, 1016, https://doi.org/10.1002/(SICI)1522-2675(19990707)82:7<1016::AIDHLCA1016>3.0.CO;2-Y.

[41] F. Etzweiler, D. Helmlinger, C. Nussbaumer, M. Pesaro, Patent No. EP464357A2, 1992.

[42] S. Hong, E. J. Corey, J. Am. Chem. Soc. 2006, 128, 1346 , https://doi.org/10.1021/ja057483x.

[43] N. Armanino, J. Charpentier, F. Flachsmann, A. Goeke, M. Liniger, P. Kraft, Angew. Chem. 2020, 132, 16450, https://doi.org/10.1002/ange.202005719.

\section{License and Terms}

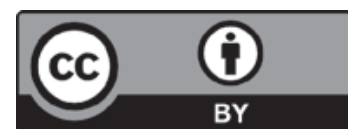

This is an Open Access article under the terms of the Creative Commons Attribution License CC BY 4.0. The material may not be used for commercial purposes.

The license is subject to the CHIMIA terms and conditions: (http:// chimia.ch/component/sppagebuilder/?view=page $\& i d=12$ ).

The definitive version of this article is the electronic one that can be found at https://doi.org/10.2533/chimia.2021.780 